\title{
Pengaruh Perbedaan Keterangan Saksi Jarimah Zina (Perpektif Hukum Positif dan Hukum Pidana Islam)
}

\author{
Islamul Haq \\ IAIN Parepare \\ Email: Islamulhaq@iainpare.ac.id
}

\begin{abstract}
This study aims to examine the influence of witnesses' different opinion in adultery jarimah verification on suspect determination between positive law and Islamic criminal law perspectives.This research adapts library research (library research) conducted through reading, understanding books, theses, dissertations, websites and other literature related to problems by content analysis and the comparative approach between positive law and Islamic criminal law.The results of this study indicates that in a positive law, different witness testimonies can release a suspect from a guilty charge especially if the crime of adultery is lone standing criminal (Zelfstanding Delict).In the case of act of continuing (voortgezette handeling), differences in the testimony of witnesses does not make witness statements denied as long as the difference in witness testimony does not exceed the set limits. In Islamic Criminal Law, If there are differences in the statements of the four witnesses, all witnesses' opinions cannot be accepted unless the differences of opinion regarding time and place are not far apart.
\end{abstract}

\begin{abstract}
Abstrak
Penelitian ini bertujuan untuk mengetahui bagaimana pengaruh perbedaan pendapat saksi dalam pembuktian jarimah zina terhadap penetapan tersangka persfektif hukum positif dan hukum pidana Islam. Penelitian ini merupakan penelitian kepustakaan (library research), yaitu metode yang menggunakan riset kepustakaan baik melalui membaca, memahami buku-buku, tesis, disertasi, website maupun literatur lainnya yang sifatnya pustaka terkait dengan permasalahan dalam rangka memperoleh data, menggunakan analisis kontent (content analyzis) dan metode komparasi antara hukum positif dan hukum pidana Islam. Hasil penelitian ini menunjukkan bahwa dalam hukum positif perbedaan keterangan saksi dapat membebaskan tersangka dari tuntutan bersalah, khususnya jika tindak pidana zina tersebut merupakan tindak pidana yang berdiri sendiri (Zelfstanding Delict). Berbeda jika
\end{abstract}


tindak pidana zina merupakan perbuatan berlanjut (voortgezette handeling) perbedaan keterangan saksi tidak menjadikan keterangan saksi ditolak sepanjang perbedaan keterangan saksi tidak melewati batas yang telah ditetapkan. Dalam Hukum Pidana Islam Jika terjadi perbedaan keterangan pada keempat saksi, maka semua pendapat saksi tidak dapat diterima kecuali jika perbedaan pendapat mengenai waktu dan tempat tidak berjauhan.

Keywords: Hukum Positif, Voortgezette handeling, Zelfstanding Delict

\section{Pendahuluan}

Salah satu masalah serius yang dihadapi dunia Islam dewasa ini adalah masalah perzinaan, tidak terkecuali di Indonesia. Indonesia yang mayoritas penduduknya umat Islam dan menjadikan Pancasila sebagai dasar negara seharusnya menjunjung tinggi akhlak mulia yang menolak segala mancam bentuk jarimah (tindak pidana) perzinaan. Pada kenyataannya, pergeseran nilai kesusilaan dalam masyarakat tertentu telah terjadi. Hal tersebut dapat dilihat dari perilaku sebagian pelaku zina yang semakin berani dan tidak tercermin rasa bersalah (Sundah 2017). Tindak pidana perzinaan yang semakin marak menimbulkan dampak negatif terhadap pelaku kejahatan. Hal ini menjadi salah satu masalah yang harus segera ditanggulangi oleh pihak-pihak terkait.

Usaha penanggulangan terhadap maraknya tindak pidana perzinaan, dilakukan secara preventif maupun represif (Hidayat 2017). Preventif dilakukan dengan langkahlangkah pencegahan, seperti penyuluhan-penyuluhan tentang bahaya zina sedangkan secara represif dilakukan dengan jalan menindak pelaku tindak pidana yang biasanya dilaksanakan melalui rangkaian proses penyelesaian perkara pidana, mulai dari Penyelidikan dan Penyidikan, Penuntutan, Pemeriksaan sampai kepada pemutusan perkara di Pengadilan.

Dalam proses penyelesaian perkara pidana keterangan saksi merupakan salah satu alat buktiyang terpenting (Kawengian 2016). Sebagian besar terungkapnya kasus kejahatan di Indonesia berasal dari keterangan masyarakat. Keterangan saksi memiliki peran yang sangat penting dalam menetapkan tersangka. Untuk menjatuhkan hukuman terhadap tersangka pelaku tindak pidana, sangat bergantung kepada hasil pemeriksaan hakim di pengadilan. Dalam Kitab Undang-undang Hukum Acara Pidana (KUHAP) pasal 184 disebutkan bahwa yang dapat dipergunakan sebagai alat bukti adalah alat bukti yang sah yang terdiri dari keterangan saksi, keterangan ahli, surat, petunjuk, dan keterangan terdakwa.

Salah satu alat bukti sebagaimana yang telah disebutkan dalam KUHAP pasal 184 adalah katerangan saksi. Keterangan saksi ini selalu dengan apa yang dilihat, dialami atau apa yang didengar oleh saksi yang bersangkutan (Hamzah 1987). Keberadaan saksi sangat penting karena aparat penegak hukum akan mengalami kesulitan dalam mencari dan menemukan kejelasan tentang tindak pidana tanpa keberadaan saksi.

al-ạ̣kām Vol. 5, Nomor 1, 2020 
Dalam hukum pidana Islam, persaksian juga merupakan salah satu alat bukti utama dalam penetapan hukum terhadap pelaku tindak pidana (Khoiriyah 2014), hukum persaksian sebagai salah satu alat bukti disebutkan di dalam Alquran surah Al-baqarah ayat 282:

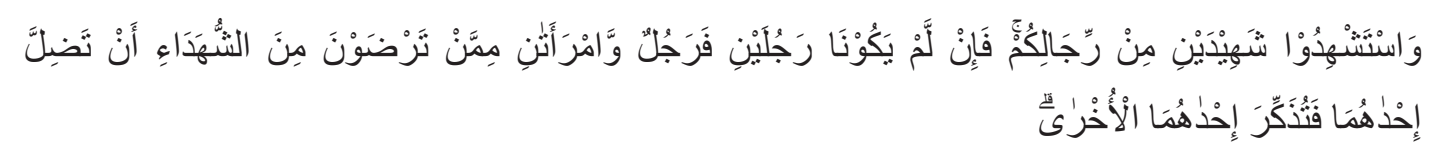

"Dan persaksikanlah dengan dua orang saksi laki-laki di antara kamu. Jika tidak ada (saksi) dua orang laki-laki, maka (boleh) seorang laki-laki dan dua orang perempuan di antara orang-orang yang kamu sukai dari saksi (yang ada), agar jika seorang lupa maka yang seorang lagi mengingatkannya."

Dalam hadis Nabi yang diriwayatkan oleh Imam An-Nasai disebutkan:

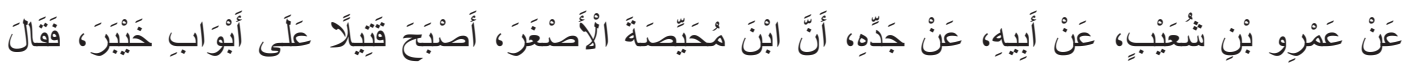

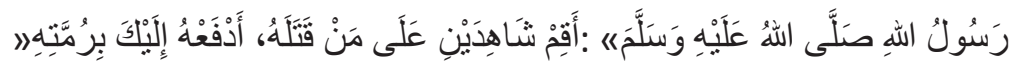

"Dari 'Amr ibn Syu'aib dari ayahnya dari kakeknya, bahwa anaknya Muhaishah yang paling kecil ditemukan terbunuh di pintu Khaibar. Maka Rasulullah saw, bersabda, "Ajukanlah dua orang saksi atas orang yang membunuhnya, nanti saya berikan kepadamu tambang untuk mengqishasnya." (Al-Nasa'i 2001).

Ayat dan hadis di atas juga menjelaskan kepada kita bahwa persaksian merupakan salah satu alat bukti dalam penetapan tindak pidana. Selain itu, ayat dan hadis tersebut juga menunjukkan bahwa jumlah saksi dalam hukum pidana Islam adalah minimal dua orang saksi laki-laki atau seorang laki-laki dan dua orang perempuan bahkan dalam tindak pidana perzinaan hukum pidana Islam mewajibkan adanya empat orang saksi. Hukum Islam juga mengharuskan kepada setiap orang yang melihat, mengalami, dan mendengar suatu tindak pidana untuk menjadi saksi dalam persidangan. Hal tersebut disebutkan di dalam Alquran surat Al-baqarah ayat 283. "Dan janganlah kamu (saksi) menyembunyikan persaksian. Dan barangsiapa yang menyembunyikannya, maka sesungguhnya ia adala orang yang berdosa hatinya; dan Allah Maha Mengetahui apa yang kamu kerjakan."

Aturan tentang saksi tindak pidana perzinaan dalam hukum pidana Islam dan hukum positif sangat berbeda (Adrosin 2015). Dalam Hukum Pidana Islam saksi tindak pidana perzinaan harus berjumlah empat orang laki-laki muslim, yang amanah, apabila di antara saksi-saksi tersebut terdapat saksi wanita maka saksi wanita harus berjumlah dua orang untuk mengantikan kedudukan satu saksi laki-laki dan memenuhi syarat saksi dalam hukum pidana Islam, yaitu balig, berakal, muslim, adil dan dapat dipercaya (Huda 2015). Sedangkan 
dalam hukum positif, satu orang saksi sudah dapat menjadi bukti dalam penetapan tindak pidana. Hukum positif juga tidak membedakan jumlah saksi antara laki-laki dan perempuan yang penting memenuhi syarat untuk menjadi seorang saksi, yaitu mengucapkan sumpah, katerangan yang disampaikan saksi sesuai dengan peristiwa pidana yang ia alami dan saksikan sendiri, keterangan saksi harus diberikan di pengadilan (Adzimah 2015).

Banyaknya saksi dalam persidangan seperti yang disyaratkan terhadap tindak pidana perzinaan dalam hukum pidana Islam terkadang menyebabkan terjadinya perbedaan argumen saksi baik dari segi waktu kejadian, tempat kejadian, cara melakukan tindak pidana, jumlah pelaku dan sebagainya. Hal ini dapat menimbulkan pengaruh terhadap pengambilan keputusan oleh hakim.

\section{Metode Penelitian}

Penelitian ini adalah penilitian kualitatif, menggunakan pendekatan hukum yuridis normatif yang bersifat deskriptif-komparatif. Teknik pengumpulan data dilakukan dengan cara penelusuran kepustakaan (library-research) dengan meneliti beberapa sumber di antaranya Alquran, Hadis, undang-undang, KUHP, KUHAP dan beberapa sumber lainnya seperti buku-buku tentang hukum, makalah, jurnal, artikel website, berita, majalah dan Koran. Untuk memperkuat data-data penelitian dilakukan wawancara kepada hakim yang memberikan putusan terkait dengan judul penelitian.

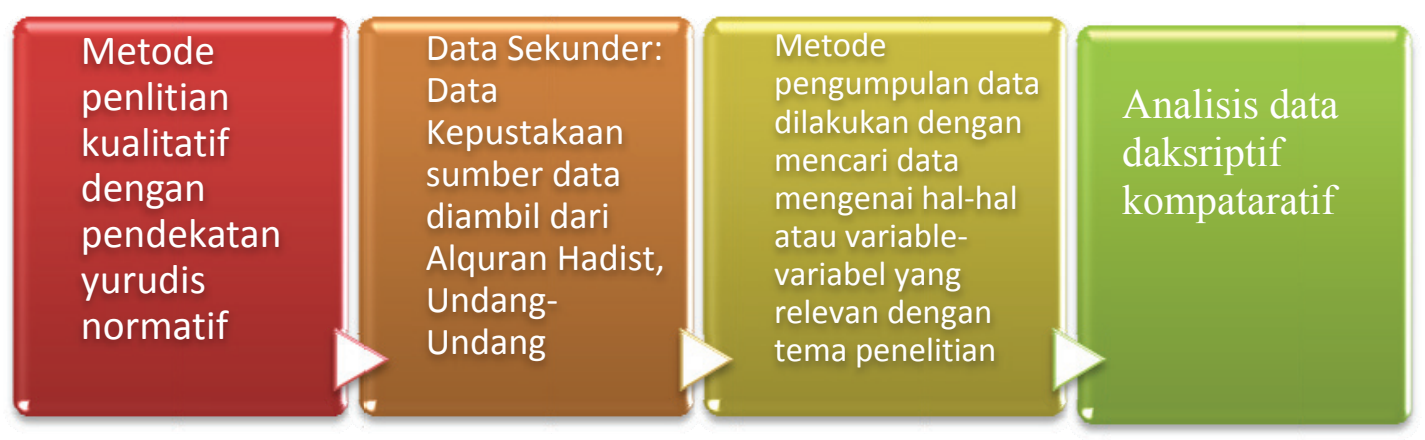

\section{Penelitian Terdahulu}

Untuk mendukung penelitian ini, maka peneliti berusaha melakukan penelusuran di berbagai karya ilmiah. Secara umum, pembahasan tentang keterangan saksi dalam tindak pidana telah banyak diteliti dan dituangkan dalam bentuk tulisan. Namun, pembahasan mengenai perbedaan pendapat saksi dalam menetapkan hukuman yang yang mengomparasikan antara hukum positif dan hukum Islam belum ditemukan peneliti sama sekali.

\footnotetext{
al-aḥ̂ām vol. 5, Nomor 1, 2020
} 
Di antara karya ilmiah yang membahas tentang saksi adalah sebagai berikut:

\begin{tabular}{|c|c|c|c|c|c|}
\hline No & Peneliti & Judul Penelitian & Hasil Penelitian & Persamaan & Perbedaan \\
\hline 1 & $\begin{array}{l}\text { Betha Intan } \\
\text { Junetha }\end{array}$ & $\begin{array}{l}\text { Kekuatan Alat } \\
\text { Bukti Keterangan } \\
\text { Saksi Yang Berbeda } \\
\text { Antara Berita } \\
\text { Acara Pemeriksaan } \\
\text { Di Penyidik Dengan } \\
\text { Keterangan Saksi } \\
\text { Di Persidangan } \\
\text { Terhadap Putusan } \\
\text { Hakim Nomor } \\
\text { 465/PID.B/2009/ } \\
\text { PN.BJN" }\end{array}$ & $\begin{array}{l}\text { peneliti dalam } \\
\text { jurnal ini } \\
\text { berkesimpulan } \\
\text { bahwa keterangan } \\
\text { saksi tidak } \\
\text { mempunyai } \\
\text { kekuatan hukum } \\
\text { di persidangan } \\
\text { suatu pembuktian } \\
\text { melalui keterangan } \\
\text { saksi yang } \\
\text { sumbernya dari } \\
\text { orang lain maka } \\
\text { tidak memiliki } \\
\text { kekuatan hukum } \\
\text { pembuktian. }\end{array}$ & $\begin{array}{l}\text { Sama-sama } \\
\text { membahas } \\
\text { perbedaan } \\
\text { pendapat } \\
\text { saksi }\end{array}$ & $\begin{array}{l}\text { Jurnal ini } \\
\text { hanya } \\
\text { membahas } \\
\text { Terhadap } \\
\text { Putusan } \\
\text { Hakim } \\
\text { Nomor 465/ } \\
\text { PID.B/2009/ } \\
\text { PN.BJN" tidak } \\
\text { membahas } \\
\text { tentang } \\
\text { jarimah zina }\end{array}$ \\
\hline 2 & Suisno & $\begin{array}{l}\text { "Peranan } \\
\text { Keterangan Saksi } \\
\text { Sebagai Salah Satu } \\
\text { Alat Bukti Dalam } \\
\text { Proses Pidana" }\end{array}$ & $\begin{array}{l}\text { Hasil penelitian } \\
\text { ini menujukkan } \\
\text { pentingnya } \\
\text { keterangan saksi } \\
\text { yang merupakan } \\
\text { salah satu alat } \\
\text { bukti yang } \\
\text { mempunyai } \\
\text { kekuatan } \\
\text { pembuktian kuat, } \\
\text { utamanya dalam } \\
\text { usaha untuk } \\
\text { membuktikan } \\
\text { perbuatan materil } \\
\text { tindak pidana }\end{array}$ & $\begin{array}{l}\text { Sama-sama } \\
\text { membahas } \\
\text { tentang } \\
\text { Alat bukti } \\
\text { keterangan } \\
\text { saksi }\end{array}$ & $\begin{array}{l}\text { Jurnal ini tidak } \\
\text { membahas } \\
\text { mengenai } \\
\text { perbedaan } \\
\text { pendapat saksi } \\
\text { dalam jarimah } \\
\text { zina }\end{array}$ \\
\hline 3 & $\begin{array}{l}\text { Johar } \\
\text { Moidadi }\end{array}$ & $\begin{array}{l}\text { “Peranan } \\
\text { Saksi Yang } \\
\text { Menguntungkan } \\
\text { Terdakwa } \\
\text { Dalam Proses } \\
\text { Pemeriksaan } \\
\text { Perkara Pidana } \\
\text { (Studi Pn. Palu } \\
\text { Nomor 10/PID. } \\
\text { SUSTIPIKOR /2013/ } \\
\text { PN.PL) }\end{array}$ & $\begin{array}{l}\text { kesimpulan jurnal } \\
\text { ini menyebutkan } \\
\text { bahwa peranan } \\
\text { saksi yang } \\
\text { memberikan } \\
\text { keuantungan } \\
\text { kepada terdakwa } \\
\text { pada proses } \\
\text { persidangan sangat } \\
\text { berpengaruh }\end{array}$ & $\begin{array}{l}\text { Sama-sama } \\
\text { membahas } \\
\text { tentang } \\
\text { Alat bukti } \\
\text { keterangan } \\
\text { saksi }\end{array}$ & $\begin{array}{l}\text { Jurnal ini tidak } \\
\text { membahas } \\
\text { mengenai } \\
\text { perbedaan } \\
\text { pendapat saksi } \\
\text { dalam jarimah } \\
\text { zina }\end{array}$ \\
\hline
\end{tabular}




\begin{tabular}{|c|c|c|c|c|c|}
\hline & & & $\begin{array}{l}\text { terhadap } \\
\text { hakim dalam } \\
\text { menjatuhkan } \\
\text { putusan }\end{array}$ & & \\
\hline 4 & $\begin{array}{l}\text { Febri Sri } \\
\text { Utami }\end{array}$ & $\begin{array}{l}\text { Kedudukan } \\
\text { Keterangan Saksi di } \\
\text { Penyidikan Sebagai } \\
\text { Alat Bukti Yang Sah } \\
\text { Dalam Persidangan } \\
\text { (Studi Putusan } \\
\text { Pengadilan Negeri } \\
\text { Stabat No.752/ } \\
\text { Pid.B/ 2012/ } \\
\text { PN.Stb) }\end{array}$ & $\begin{array}{l}\text { Hasil penelitian ini } \\
\text { menyatakan bahwa } \\
\text { Menjadi saksi } \\
\text { merupakan suatu } \\
\text { kewajiban hukum } \\
\text { (Legal obligation) } \\
\text { bagi setiap orang. } \\
\text { Keterangan saksi } \\
\text { sebagai alat bukti } \\
\text { memeliki peranan } \\
\text { yang sangat } \\
\text { urgent dalam } \\
\text { ihwal pemeriksaan } \\
\text { perkara di sidang } \\
\text { pengadilan }\end{array}$ & $\begin{array}{l}\text { Sama-sama } \\
\text { membahas } \\
\text { tentang } \\
\text { Alat bukti } \\
\text { keterangan } \\
\text { saksi }\end{array}$ & $\begin{array}{l}\text { Jurnal ini tidak } \\
\text { membahas } \\
\text { mengenai } \\
\text { perbedaan } \\
\text { pendapat saksi } \\
\text { dalam jarimah } \\
\text { zina }\end{array}$ \\
\hline
\end{tabular}

\section{Perbedaan Pendapat Saksi Jarimah Zina dalam Hukum Positif}

Sesuai dengan KUHP yang berlaku saat ini di Indonesia, syarat penjatuhan vonis bersalah merujuk kepada KUHP pasal 183 yaitu adanya dua alat bukti yang disertai dengan keyakinan hakim. Di antara alat-alat bukti yang telah disebutkan pada bab sebelumnya yaitu keterangan saksi, keterangan ahli, surat, petunjuk dan keterangan terdakwa. Jadi untuk menetapkan bersalah atau tidaknya seseorang harus dibuktikan paling sedikit dua jenis alat bukti sebagaimana yang tertuang dalam KUHP pasal 183: " Hakim tidak boleh menjatuhkan pidana kepada seorang kecuali apabila dengan sekurang-kurangnya dua alat bukti yang sah ia memperoleh keyakinan bahwa suatu tindak pidana benar-benar terjadi dan terdakwalah yang bersalah melakukannya".

Apabila syarat sekurang-kurangnya minimal dua alat bukti tidak tercapai, maka perbuatan tersebut dengan sendirinya mengenyampingkan standar Beyond a reasonable doubt jika hukuman dijatuhkan kepada tersangka maka itu dianggap sebagai sebuah kesewengan-wanangan (Ichsan Zikry 2014)(Haq 2017).

Prinsip minimum pembuktian yang diatur dalam pasal 183 KUHP menjadikan keterangan satu orang saksi saja tidak cukup untuk dijadikan dasar penjatuhan vonis bersalah, karena keterangan satu orang saksi baru bernilai satu alat bukti yang harus ditambah dengan alat bukti lainnya sesuai dengan prinsip "unus testis nullus testis", ketentuan jumlah saksi diatur dalam pasal 185 ayat 2 yang berbunyi: (1) untuk dapat membuktikan kesalahan terdakwa paling sedikit harus didukung oleh "dua orang saksi", (2) atau kalau saksi yang ada 
hanya terdiri dari seorang saja maka kesaksian tunggal itu harus "dicukupi" atau "ditambah" dengan salah satu alat bukti yang lain.

Dalam menilai kebenaran keterangan seorang saksi menurut ketentuan Pasal 185 ayat (6) KUHAP, Hakim harus dengan sungguh-sungguh memperhatikan aspek-aspek: (1) Persesuaian antara keterangan saksi satu dengan yang lain; (2) Persesuaian antara keterangan saksi dengan alat bukti yang lain; (3) Alasan yang mungkin dipergunakan oleh saksi untuk memberi keterangan yang tertentu ;(4) Cara hidup dan kesusilaan saksi serta segala sesuatu yang pada umumnya dapat mempengaruhi dapat tidaknya keterangan itu dipercaya (Saleh 2013).

Pasal 185 ayat (6) menjelaskan bahwa, harus ada keseuaian antara satu keterangan saksi dengan keterangan saksi lainnya, pasal ini berlaku secara mutlak, artinya jika terjadi ketidaksesuaian antara satu keterangan saksi dengan keterangan saksi yang lain, maka persaksian tidak dapat diterima, baik ketidaksesuaian itu terjadi pada pelaku, tempat, waktu maupun tindakan perzinaan.

Menurut Muhammad Hakim (hakim Pengadilan Negeri kab. Pangkep) beliau mengatakan tentang ketidaksesuaian keterangan saksi bahwa: "kalau perbedaan keterangan saksi tentang siapa pelaku tindak pidana, maka itu fatal, dalam hal ini keterangan saksi tidak dapat diterima, tapi kalau perbedaannya tidak fundamental, seperti perbedaan tentang waktu kejadian, maka jaksa bisa melakukan perluasan di dalam dakwaannya, sebuah perkara tidak dapat dikesampingkan hanya karena persoalan kekeliruan waktu" (hasil wawancara).

Hukum positif juga mengatur tentang rumusan perbuatan berlanjut (voortgezette handeling), rumusan ini tercantum di dalam pasal 64 KUHP ayat (19 yang berbunyi: "Jika antara beberapa perbuatan, meskipun masing-masing merupakan kejahatan atau pelanggaran, ada hubungannya sedemikian rupa sehingga harus dipandang sebagai satu perbuatan berlanjut, maka hanya diterapkan satu aturan pidana; jika berbeda-beda, yang diterapkan yang memuat ancaman pidana pokok yang paling berat".

Andi Hamzah mengatakan bahwa yang disarikan dari memorie Van Toelichting Pasal 64 KUHP, yaitu: dalam hal perbuatan berlanjut, pertama-tama harus ada satu keputusan kehendak (Haq, Bedong, and Syatar 2018). Perbuatan itu mempunyai jenis yang sama. Putusan hakim menunjangan arahan ini mengatakan: (1) Adanya kesatuan kehendak; (2) Perbuatan-perbuatan itu sejenis; (3) dan Faktor hubungan waktu (jarak tidak terlalu lama) (Amoi and Setyorini 2018).

Syarat adanya kesatuan kehendak cukup sulit untuk dibuktikan pada tataran praktek, karena syarat ini berhubungan dengan niat yang tidak kasat mata, oleh karena itu, yang dijadikan dasar dalam menentukan adanya satu keputusan kehendak yaitu perbuatan tersebut dilakukan kepada satu objek tindak pidana. 
Mengenai faktor hubungan waktu (jarak antara satu perbuatan dan yang lainnya tidak terlalu lama) dijelaskan bahwa dalam hal adanya tindak pidana yang antara satu dengan lainnya dipisahkan dalam 'jarak waktu lebih dari empat hari' adalah tidak tunduk pada perbuatan berlanjut, sebagaimana diatur dalam Pasal 64 KUHP, melainkan harus dianggap sebagai perbarengan beberapa tindak pidana. Jadi untuk dikatakan sebagai sebuah perbuatan berlanjut maka jarak waktu perbuatan tidak melebihi masa empat hari.

Contoh perbuatan berlanjut sebagaimana yang disebutkan oleh Tirtaamidjaja yaitu: "si A ingin berzina dengan seorang wanita B yang telah bersuami, si A melaksanakan keinginannya berzina beberapa kali dengan si B dalam rentang waktu yang tidak terlalu lama"(Tirtaämidjaja 1955).

Berdasarkan uraian di atas, peneliti berkesimpulan bahwa jika suatu tindak pindana merupakan tindak pidana berlanjut, maka perbedaan keterangan saksi mengenai waktu, tempat kejadian perkara, tidak membuat keterangan saksi ditolak sepanjang rentang waktu tindak pidana tersebut tidak melebihi batas empat hari. Akan tetapi jika perbedaan keterangan dua orang saksi terjadi pada tindak pidana yang berdiri sendiri (Zelfstanding Delict), maka dalam hal ini keterangan saksi tidak dapat diterima .

\section{Perbedaan Pendapat Saksi Jarimah Zina Dalam Hukum Pidana Islam}

Salah satu syarat yang harus dipenuhi dalam pembuktian jarimah zina dengan kesaksian (bayyinah) adalah adanya empat orang saksi laki-laki, keempat saksi tersebut harus memberikan kesaksian terhadap tindakan yang sama, pada tempat yang sama dan waktu yang sama.

Apabila terjadi perbedaan keterangan pada keempat saksi, baik perbedaan itu pada waktu, tempat kejadian maupun perbedaan pada tindakan perzinaan, maka hal tersebut tidak lepas dari tiga keadaan yaitu:

Keadaan pertama: perbedaan waktu dan tempat yang disebutkan saksi tidak berjauhan, misalnya jika dua orang saksi memberikan keterangan bahwa tersangka melakukan perzinaan di salah satu sudut pada rumah kecil, sedang dua saksi lainnya mengatakan bahwa tersangka melakukan perzinaan di sudut lain dari rumah tersebut dan kedua sudut rumah saling berdekatan atau dua orang saksi memberikan keterangan bahwa tersangka melakukan perzinaan pada hari Sabtu pukul 22.00 sementara dua saksi lainnya mengatakan tersangka melakukan perzinaan pada hari Sabtu pukul 23.00, maka terdapat dua pendapat ulama tentang keadaan tersebut, yaitu:

Pendapat pertama, pendapat dari kalangan mazhab Hanafi dan mazhab Hanbali mengatakan jika terjadi perbedaan pendapat saksi dalam jarimah zina seperti pada keadaan pertama maka pendapat saksi tetap diterima dan tersangka dapat dijatuhi hukuman had,

al-ạ̣kān Vol. 5, Nomor 1, 2020 
karena adanya kemungkinan permulaan perzinaan dilakukan di salah satu pojok rumah dan berakhir di pojok lainnya. Adapun jika rumahnya luas, maka kesaksian seperti ini tidak dapat diterima, karena kesaksian tersebut disamakan dengan kesaksian di dua rumah (tempat kejadiannya tidak sama (Kasani, n.d.).

Pendapat kedua, pendapat ulama dari kalangan mazhab Syafiiyah dan mazhab Malikiyah mengatakan, kesaksian seperti ini tidak dapat diterima dan tidak dapat dijadikan hujjah dalam menetapkan hukuman had karena para saksi tidak bersepakat pada satu perzinaan (al-Khathib 1985). Zina yang disaksikan pada salah satu sudut rumah tidak sama dengan zina yang disaksikan pada sudut lain dari rumah tersebut.

Penulis lebih condong kepada pendapat pertama yang mengatakan perbedaan pendapat saksi mengenai tempat dan waktu kejadian yang saling berdekatan tidak berpengaruh terhadap kekuatan pendapat saksi karena pendapat saksi dalam hal dapat diterima sebagai satu rangkaian perbuatan zina disebabkan adanya kemungkinan permulaan perzinaan dilakukan di salah satu pojok rumah dan berakhir di pojok lainnya, sama halnya dengan perbedaan waktu yang tidak jauh karena adanya kemungkinan perbuatan zina berlangsung selama jangka waktu yang disebutkan.

Keadaan kedua: Perbedaan waktu dan tempat yang disebutkan saksi saling berjauhan, misalnya, jika dua orang saksi memberikan keterangan bahwa tersangka melakukan perzinaan di salah satu kota sedang saksi yang lain memberikan keterangan bahwa tersangka melakukan perzinaan di kota lain atau dua orang saksi pertama mengatakan bahwa tersangka melakukan perzinaan pada hari Kamis sementara dua saksi lainnya mengatakan bahwa tersangka melakukan perzinaan pada hari Senin dalam hal ini ulama berbeda pendapat

Pendapat pertama, pendapat mayoritas ulama dari mazhab Hanafi, Maliki, Syafi'i dan Hanbali mengatakan dalam hal ini saksi tidak dapat diterima persaksiannya dan tersangka tidak dapat dijatuhi hukuman had zina. Dalil mereka adalah perzinaan yang disaksikan oleh para saksi pada tempat dan waktu yang berbeda adalah dua perbuatan zina yang berbeda bukan satu rangkaian perbuatan zina dalam satu waktu, maka persaksiannya tidak diterima karena tiap perbuatan zina dalam hal ini tidak memenuhi syarat empat orang saksi, sementara satu perbuatan tidak mungkin dilakukan pada satu waktu di tempat yang berbeda(Kasani, n.d.).

Pendapat kedua, pendapat sabagian ulama dari mazhab Malik dan Hanbali dan Dhahiri mengatakan bahwa perbedeaan pendapat saksi dalam hal ini tidak berpengaruh terhadap diterima atau tidaknya keterangan saksi. Dalil mereka adalah bahwa umumnya nash-nash yang berkaitan dengan saksi perzinaan menunjukkan bahwa yang diwajibkan bagi saksi adalah membuktikan perbuatan zina tanpa melihat apakah kesaksiannya berbeda tempat atau waktu (Hazm 2003). 
Keadaan ketiga: Perbedaan pendapat saksi pada tindakan perzinaan, atau cara melakukan perbuatan zina, misalnya dua saksi pertama mengatakan si A berzina dengan cara berbaring, dua saksi lainnya mengatakan si A berzina dengan cara berdiri, maka ulama berbeda pendapat sebagaimana berikut:

Pendapat Pertama, pendapat mayoritas ulama baik dari kalangan Mazhab Hanafi, Mazhab Maliki, Mazhab Syafi'i dan Mazhab Hanbali mengatakan bahwa semua keterangan saksi mengenai tindakan perzinaan harus seragam, apabila terjadi perbedaan keterangan saksi, termasuk perbedaan keterangan pada tindakan zina, maka semua persaksisan tidak dapat diterima.

Dalil pendapat pertama adalah kisah Maiz ketika mengaku berzina di hadapan Rasulullah lalu Rasulullah saw. menanyakan: "Apakah sampai 'milikmu' terbenam ke dalam 'miliknya', sebagaimana pensil celak masuk ke tempat celak dan tali timba masuk ke dalam sumur?, Maiz menjawab: Iya. Apabila penjelasan tentang tindakan perzinaan (cara melakukan zina) dipertimbangkan dalam pengakuan, maka lebih utama untuk dipertimbangkan dalam persaksian. Dalil kedua yaitu jika para saksi tidak menjelaskan tindakan perzinaan secara terperinci, kemungkinan besar tersangka tidak dapat dijatuhkan hukuman had, maka para saksi harus menyingkap peristiwa perzinaan secara rinci.

Pendapat kedua, Pendapat ulama dari kalangan ulama Adzahiriyah mengatakan bahwa perbedaan pendapat tentang tindakan perzinaan tidak berpengaruh dengan kekuatan persaksian dan tersangka dapat dijatuhi hukuman had. Dalil pendapat kedua yaitu tidak ada dalil yang mewajibkan untuk menjelaskan secara terperinci mengenai tindakan (cara melakukan) perzinaan, apabila syarat empat orang saksi yang adil sudah terpenuhi, maka kesaksian sudah dapat diterima.

Menurut hemat peneliti pendapat yang paling kuat adalah pendapat pertama yang mengatakan bahwa semua keterangan saksi mengenai tindakan perzinaan harus seragam, apabila terjadi perbedaan keterangan saksi, termasuk perbedaan keterangan pada tindakan zina, maka semua persaksisan tidak dapat diterima karena kuatnya dalil yang mereka sampaikan dan perbedaan keterangan saksi merupakan syubhat dan had tidak dapat dijatuhkan ketika terdapat syubhat.

Berdasarkan uraian di atas diketahui bahwa pembuktian jarimah Zina dalam Hukum Pidana Islam sangat ketat, harus empat orang saksi yang melihat kejadian secara langsung dan tidak terdapat perbedaan keterangan saksi, baik perbedaan itu mengenai waktu atau tempat kejadian maupun mengenai tindakan perzinaan. Faktor hubungan waktu dan tempat (jarak antara satu perbuatan) dalam hukum pidana Islam sangat sempit, meski tidak ada batasan waktu yang jelas disebutkan oleh para ulama, tapi dapat disimpulkan dari beberapa pendapat ulama bahwa batasan waktu dikembalikan kebiasaan durasi waktu saat berhubungan badan. Berdasarkan jajak pendapat yang dilakukan oleh fox news tahun 2007,

al-ạ̣kān Vol. 5, Nomor 1, 2020 
rata-rata waktu yang dibutuhkan saat berhubungan badan adalah sekitar enam menit(CNN Indonesia 2019). Adapun batasan tempat adalah tempat yang sempit seperti rumah sempit yang sudut-sudutnya dapat terjangkau ketika seseorang melakukan satu tindak pidana perzinaan.

Pada umumnya, tindak pidana zina dalam hukum pidana Islam adalah tindak pidana yang berdiri sendiri (Zelfstanding Delict), sehingga ketika terjadi pengulangan zina, maka tiap-tiap tindak pidana harus memenuhi semua syarat-syarat pembuktian, misalnya jika si A melakukan perzinaan pada hari Selasa di salah satu hotel, kemudian keesokan harinya ia kembali melakukan zina di hotel lain atau di hotel yang sama, maka masing-masing perbuatan harus memenuhi syarat persaksian untuk dapat dijatuhkan hukuman had kepada si A. Jika terdapat dua orang saksi pada perbuatan zina yang dilakukan pada hari pertama, kemudian dua orang saksi lainnya pada hari kedua, maka ini belum dianggap memenuhi syarat empat orang saksi, karena masing-masing perbuatan harus disaksikan minimal empat orang saksi.

\section{Komparasi antara Hukum Positif dan Hukum Pidana Islam Terhadap Perbedaan Pendapat} Saksi Jarimah Zina

Pembuktian jarimah zina dalam hukum positif berdasar kepada KUHP pasal 183 yaitu adanya dua alat bukti yang disertai dengan keyakinan hakim. Hukum positif tidak memberikan syarat terhadap jumlah saksi yang harus dihadirkan di persidangan, ketika syarat minimun adanya dua alat bukti serta keyakinan hakim terpenuhi, maka vonis sudah dapat dijatuhkan kepada tersangka.

Hukum Positif menganut sistem pembuktian negatief wettelijk bewijstheorie atau pembuktian berdasarkan undang-undang secara negatif adalah pembuktian yang selain menggunakan alat-alat bukti yang dicantumkan di dalam undang-undang, juga menggunakan keyakinan hakim. Sekalipun menggunakan keyakinan hakim, namun keyakinan hakim terbatas pada alat-alat bukti yang ditentukan dalam undang- undang. Sistem pembuktian ini menggabungkan antara sistem pembuktian menurut undang- undang secara positif dan sistem pembuktian menurut keyakinan hakim sehingga sistem pembuktian ini disebut pembuktian berganda (doubelen grondslag) (Muhammad 2007). Jadi meskipun dalam proses persidangan diajukan dua alat bukti atau lebih akan tetapi alat bukti tersebut tidak meyakinan hakim bahwa terdakwa bersalah maka terdakwa tersebut dapat dibebaskan.

Perbedaan keterangan saksi tentang waktu, tempat dan tindakan perzinaan akan berpengaruh terhadap keyakinan hakim. Pasal 185 ayat (6) KUHAP juga menginginkan adanya persesuaian antara keterangan saksi satu dengan yang lain, hal ini mengisyaratkan bahwa perbedaan keterangan saksi dapat membebaskan tersangka dari tuntutan bersalah, khususnya jika tindak pidana zina tersebut merupakan tindak pidana yang berdiri sendiri (Zelfstanding Delict). 
Berbeda jika tindak pidana zina merupakan perbuatan berlanjut (voortgezette handeling), perbedaan keterangan saksi mengenai waktu, tempat kejadian serta tindakan perzinaan tidak menjadikan keterangan saksi ditolak sepanjang perbedaan keterangan saksi tidak melewati batas yang telah ditetapkan.

Dalam Islam, hukuman bagi pelaku tindak pidana zina sangat berat, yaitu cambuk seratus kali bagi pelaku yang tidak muhsan (belum menikah) dan rajam bagi pelaku muhsan (telah menikah), hal ini berbanding lurus dengan syarat pembuktian yang sangat ketat, syarat saksi jarimah zina dalam hukum Islam adalah adanya empat orang saksi laki-laki yang menyaksikan secara langsung peristiwa zina, keempat saksi juga harus memberikan kesaksian terhadap tindakan yang sama, pada tempat yang sama dan waktu yang sama. Jika terjadi perbedaan keterangan pada keempat saksi, baik perbedaan itu pada waktu, tempat kejadian maupun perbedaan pada tindakan perzinaan maka perbedaan tersebut tidak terlepas dari tiga keadaan yaitu:

Perbedaan waktu dan tempat yang disebutkan saksi tidak berjauhan, dalam hal ini peneliti lebih memilih pendapat ulama yang mengatakan Penulis lebih condong kepada pendapat pertama yang mengatakan perbedaan pendapat saksi mengenai tempat dan waktu kejadian yang saling berdekatan tidak mempengaruhi kekuatan pendapat saksi karena pendapat saksi dalam hal ini dapat diterima sebagai satu rangkaian perbuatan zina disebabkan adanya kemungkinan permulaan perzinaan dilakukan di salah satu pojok rumah dan berakhir di pojok lainnya.

Perbedaan waktu dan tempat yang disebutkan saksi berjauhan, Peneliti merajihkan pendapat pendapat mayoritas ulama dari mazhab Hanafi, Maliki, Syafi'i dan Hanbali yang mengatakan bahwa ketika perbedaan waktu dan tempat yang disebutkan saksi saling berjauhan maka pendapat saksi tidak dapat diterima, karena perzinaan yang disaksikan oleh para saksi pada tempat dan waktu yang berbeda adalah dua perbuatan zina yang berbeda bukan satu rangkaian perbuatan zina dalam satu waktu, maka persaksiannya tidak diterima, pada kasus seperti ini tiap perbuatan zina tidak memenuhi syarat empat orang saksi, sementara satu perbuatan tidak mungkin dilakukan pada satu waktu di tempat yang berbeda.

Perbedaan pendapat saksi pada tindakan perzinaan, atau cara melakukan perbuatan zina, pada kasus perbedaan seperti ini, peneliti menguatkan pendapat ulama yang mengatakan bahwa semua keterangan saksi mengenai tindakan perzinaan harus seragam, apabila terjadi perbedaan keterangan saksi, termasuk perbedaan keterangan pada tindakan zina, maka semua persaksisan tidak dapat diterima

Dalam Hukum positif, apabila suatu tindak pindana merupakan tindak pidana berlanjut, maka perbedaan keterangan saksi mengenai waktu, tempat kejadian perkara, tidak membuat keterangan saksi ditolak sepanjang rentan waktu tindak pidana tersebut

al-ạ̣kām Vol. 5, Nomor 1, 2020 
tidak melebihi batas empat hari. Akan tetapi jika perbedaan keterangan dua orang saksi terjadi pada tindak pidana yang berdiri sendiri (Zelfstanding Delict), maka dalam hal ini keterangan saksi tidak dapat diterima. Sementara dalam hukum pidana Islam faktor hubungan waktu dan tempat (jarak antara satu perbuatan) sangat sempit, meski tidak ada batasan waktu yang jelas disebutkan oleh para ulama, tapi dapat disimpulkan dari beberapa pendapat ulama bahwa batasan waktu dikembalikan kepada kebiasaan durasi waktu saat berhubungan badan.

\section{Kesimpulan}

Pasal 185 ayat (6) KUHAP menginginkan adanya persesuaian antara keterangan saksi satu dengan yang lain, perbedaan keterangan saksi dapat membebaskan tersangka dari tuntutan bersalah, khususnya jika tindak pidana zina tersebut merupakan tindak pidana yang berdiri sendiri (Zelfstanding Delict). Berbeda jika tindak pidana zina merupakan perbuatan berlanjut (voortgezette handeling), perbedaan keterangan saksi mengenai waktu, tempat kejadian serta tindakan perzinaan tidak menjadikan keterangan saksi ditolak sepanjang perbedaan keterangan saksi tidak melewati batas yang telah ditetapkan. Dalam Hukum Pidana Islam, hukuman bagi pelaku jarimah zina sangat berat, berbanding lurus dengan syarat pembuktian yang sangat ketat, syarat saksi jarimah zina dalam hukum Islam adalah adanya empat orang saksi laki-laki yang menyaksikan secara langsung peristiwa zina, keempat saksi juga harus memberikan kesaksian terhadap tindakan yang sama, pada tempat yang sama dan waktu yang sama. Jika terjadi perbedaan keterangan pada keempat saksi, maka semua pendapat saksi tidak dapat diterima kecuali jika perbedaan pendapat mengenai waktu dan tempat tidak berjauhan.

\section{Daftar Pustaka}

Adrosin, Pundawa. 2015. "Studi Komparatif Pemidanaan Tindak Pidana Perzinaan Dalam Hukum Positif Indonesia, RUU KUHP, Dan Hukum Pidana Islam." Jurnal Poenale 3 (2).

Adzimah, Nur. 2015. "Kedudukan Saksi Perempuan Dalam Kasus Perceraian (Analisis Perbandingan Pendapat Empat Madzhab Dengan Hukum Positif Yang Berlaku Di Indonesia)."

al-Khathib, Al-Syarbiny. 1985. "Mugni Al-Muhtaj Syarh Al-Minhaj." Kairo: al-halaby.

Al-Nasa'i, Ahmad. 2001. "Al-Sunan Al-Kubra." Hasan 'Abd Al-Man 'am Shilbi, 1-10.

Amoi, Novia Fetrisna, and Erny Herlin Setyorini. 2018. "Pencabulan Sebagai Akibat Perbuatan Berlanjut." DiH: Jurnal Ilmu Hukum.

CNN Indonesia, Mengulik Durasi Hubungan Seks Ideal. 2019. "Mengulik Durasi Hubungan Seks Ideal," April 2019. 
Hamzah, Andi. 1987. Pengantar Hukum Acara Pidana Indonesia. Ghalia Indonesia.

Haq, Islamul. 2017. "Jarimah Terhadap Kehormatan Simbol-Simbol Negara (Persfektif Hukum Pidana Indonesia Dan Hukum Pidana Islam)." Jurnal Syari'ah Dan Hukum Diktum 15 (1): 23-42.

Haq, Islamul, M Ali Rusdi Bedong, and Abdul Syatar. 2018. "Effect Of Young Age in Murder Felony (Comparative Study Between Islamic Jurisprudence and Indonesian Law)." Al-Ahkam: Jurnal Ilmu Syariah Dan Hukum 3 (2).

Hazm, Ibnu. 2003. "Al Mahalli." Bairut: Dar Al Kutub Al Ilmiyah.

Hidayat, Iman. 2017. "Analisis Normatif Tindak Pidana Perzinahan Dilihat Dalam Perspektif Hukum Islam." Jurnal IImiah Universitas Batanghari Jambi 16 (1): 44-48.

Huda, Syamsul. 2015. "Zina Dalam Perspektif Hukum Islam Dan Kitab Undang Undang Hukum Pidana." HUNAFA: Jurnal Studia Islamika 12 (2): 377-97.

Ichsan Zikry, S H. 2014. "Gagasan Plea Bargaining System Dalam RKUHAP Dan Penerapan Di Berbagai Negara."

Kasani, Abu Bakr al. n.d. "Badai'al-Shanai'fi Tartib Al-Syarai'." Beirut: Dar Al-Kutub Al-IImiyah, t. Th.

Kawengian, Tiovany A. 2016. "Peranan Keterangan Saksi Sebagai Salah Satu Alat Bukti Dalam Proses Pidana Menurut KUHAP." Lex Privatum 4 (4).

Khoiriyah, Lailatul. 2014. "Tinjauan Fiqih Murafa'at Tterhadap Penggunaan Saksi Mahkota Dalam Pembuktian Tindak Pidana Perjudian Di Pengadilan Negeri Bangkalan: Studi Analisis Putusan No. 216/PID. B/2012/PN. BKL." UIN Sunan Ampel Surabaya.

Muhammad, Rusli. 2007. Hukum Acara Pidana Kontemporer. Citra Aditya Bakti.

Saleh, Putra Akbar. 2013. "Tinjauan Yuridis Terhadap Putusan Hakim Yang Mengabaikan Bukti Keterangan Saksi Di Dalam Persidangan." Lex Et Societatis 1 (1).

Sundah, Fahri. 2017. "Tinjauan Hukum Zina Dalam Hukum Pidana Islam Dan Hukum Pidana Indonesia Serta Kontribusi Zina Dalam Pembaruan Hukum Pidana Indonesia." Fakultas Hukum UNISSULA.

Tirtaämidjaja, M H. 1955. Pokok-Pokok Hukum Pidana. Fasco. 